\title{
PENGEMBANGAN PEDAGANG KUE MELALUI NETWORKING DI KAMPUNG KUE RUNGKUT LOR, KECAMATAN RUNGKUT, SURABAYA
}

\author{
THE DEVELOPMENT OF CAKE TRADERS THROUGH NETWORKING IN \\ KAMPUNG KUE RUNGKUT LOR, RUNGKUT DISTRICT, SURABAYA
}

\author{
Maria Widyastuti", Andreas, Aldo, Alfredo \\ Prodi Manajemen, Fakultas Ekonomi, Universitas Katolik Darma Cendika, Surabaya \\ Email:mmochklas@gmail.com
}

\begin{abstract}
ABSTRAK
Surabaya memiliki sebuah komunitas yang dinamakan "Pedagang Kue" di Kampung Kue. Hadirnya komunitas pedagang kue tersebut berawal dari keinginan masyarakat untuk meningkatkan perekonomian yang lebih baik dengan menjadikan Kampung Kue sebagai kegiatan ekonomi. Terdapat 65 pedagang kue yang pada umumnya para ibu yang sudah menjajakan berbagai macam kue tradisional di depan rumahnya masing-masing. Namun, usaha mereka masih dilakukan sendiri-sendiri dan belum terorganisir dengan baik, sehingga dampaknya belum terlihat secara signifikan. Tim Pengabdian Masyarakat Universitas Katolik DarMA Cendika, membuat program yang untuk saat ini dibutuhkan antara lain: pembuatan SOP agar pekerjaan lebih efisien, konsisten dan meminimalisir kesalahan, pembukuan sederhana yang selain diperlukan untuk mengetahui perkembangan usaha, juga perlu ditanamkan pemahaman keharusan adanya pemisahan keuangan untuk usaha dan biaya keperluan pribadi. Dan membuat brosur dan katolok yang tujuannya untuk mendukung sarana promosi yang sudah ada sebelumnya. Program terakhir sebagai bentuk kepedulian terhadap situasi yang sedang terjadi yaitu adanya wabah virus corona maka tim dan warga Kampung Kue membangun Rangkaian Sprinkle Spray Desinfektan agar warga tidak ada yang terkena virus tersebut.
\end{abstract}

Kata kunci: Pengembangan Pedagang kue, Networking, Kampung Kue

\section{ABSTRACT}

Surabaya has a community called "Cake Merchant", in Kampung Kue, the presence of community cake traders in the community originated from the desire of the community to improve the economy, by making the village cake for economic activity. There are 65 pastry vendors in general mothers already peddled a variety of traditional cakes in front of their respective homes. But their efforts are still done independently and have not been well organized, so the impact has not been seen significantly. Community Dedication Team Daram Cendika Catholic University, create a program that is currently needed, among others: making SOP to work more efficiently, consistently and minimizing mistakes, simple bookkeeping in addition to the necessary to know the development of the business also needs to be implanted understanding the necessity of financial separation for business and cost of personal needs. And create brochures and katolok whose purpose is to support pre-existing promotion tools. The last Program as a form of concern for the situation that is going on is the outbreak of Corona virus, the team and residents cake build Spray disinfectant Sprinkle series so that the citizens are not affected by the virus.

Keywords: Development of Cake Traders, Networking, Kampung Kue

\section{PENDAHULUAN}

Surabaya memiliki sebuah komunitas yang dinamakan "Pedagang Kue" di Kampung Kue, tepatnya di kawasan hunian padat Rungkut Lor II, Kecamatan Rungkut. Hadirnya komunitas pedagang kue pada masyarakat berawal dari keinginan masyarakat untuk memperoleh tingkat perekonomian yang lebih baik, dengan menjadikan Kampung Kue untuk kegiatan ekonomi. Komunitas pedagang kue di Kampung Kue juga terbentuk akibat pembanguan yang terjadi di luar 
masyarakat. Tentu pembangunan Kampung Kue lebih mudah karena sudah jelas di bidang mana akan bergerak yaitu usaha membuat kue. Komunitas pedagang kue merupakan wadah untuk orang orang yang kreatif. Karena mereka harus berjuang untuk mendapatkan kehidupan yang lebih baik. Setiap dini hari, para ibu sudah menjajakan berbagai macam kue tradisional di depan rumahnya masing-masing. Mulai dari kue basah seperti pastel, lemper, dadar gulung, donat rogut, dan bolu pisang, sampai varian kue kering, salah satunya, almond crispy yang kini menjadi ikon oleh-oleh khas Surabaya.Untuk mendapat predikat sebagai "Kampung Kue" ada proses yang cukup panjang yang harus dilalui.

Pada tahun 2005 terjadi krisis ekonomi sehingga banyak ibu-ibu yang terkena PHK, dengan semangat yang tinggi untuk mandiri akhirnya berdirilah Kampung Kue. Hal ini tak lepas dari perjuangan penggagasnya, yaitu ibu Choirul Mahpuduah yang dengan kesabarannya mendorong ibu-ibu untuk membuat beraneka macam kue; dari semula 20 orang sekarang sudah mencapai 65 pembuat kue dengan bermacam macam variasi. Bahkan para bapak yang awalnya bekerja di pabrik pun kini ada yang fokus membantu istrinya untuk membuat kue. Sudah banyak ibu membuat kue tradisional yang dijajakan di pasar, namun usaha mereka masih dilakukan sendiri-sendiri dan belum terorganisir dengan baik sehingga dampaknya belum terlihat secara signifikan.

Kekuatan perempuan dapat terlihat apabila diberikan kesempatan untuk berbisnis. Kuncinya adalah memulai dan berproses, karena dari proses akan banyak belajar bagaimana membangun networking yang dapat membantu meningkatkan usahanya dalam rangka lebih memperkenalkan Kampung Kue. Manfaat dari networking mulai dari pembenahan pembukuan supaya dapat diketahui secara pasti keluar masuknya dana, cara-cara mempromosikan secara terintegrasi yang bertujuan untuk penghematan biaya karena biaya ditanggung secara bersana. Selama ini kegiatan yang berhubungan dengan pihak eksternal belum ada panduannya, maka perlu dibuat prosedur yang jelas sehingga networking yang dibangun manfaatnya dapat dirasakan secara bersama dan signifikan. Oleh karena itu, Tim Pengabdian Masyarakat Universitas Katolik Darma Cendika menjalin kerjasama dengan perempuan pembuat kue di Kampung Kue untuk membantu meningkatkan usahanya sehingga lebih dikenal oleh masyarakat secara luas yang berdampak pada peningkatan ekonomi rumah tangga. 


\section{ABDIMAS GALUH}

Volume 2, Nomor 2, September 2020, 99-108

\section{METODE PELAKSANAAN}

Sasaran kegiatan pengabdian masyarakat adalah perempuan yang tinggal di Rungkut Lor II, Kecamatan Rungkut, Surabaya. Sebelum pelaksanaan kegiatan, Tim mengadakan pertemuan dengan induk semang, penggagas berdirinya Kampung Kue dan perangkat Rukun Tetangga (RT) untuk mendapatkan arahan mengenai pelaksanaan kegiatan. Hasil pertemuan memutuskan untuk dibentuk beberapa tim, dimana setiap tim akan mendampingi induk semang yang berjumlah tujuh orang. Setiap tim mengadakan analisis pemetaan masalah yang dihadapi induk semang, dan mengadakan pertemuan untuk membahas hasil pemetaan masalah yang ada di lapangan. Selanjutnya, tim merencanakan kegiatan untuk mencari solusi atas masalah yang dihadapi melalui beberapa program. Pelaksanaan program yang telah direncanakan tim tetap melakukan diskusi dan koordinasi dengan penggagas berdirinya Kampung Kue, ketua RT serta induk semang agar sesuai dengan kebutuhannya. Induk semang yang menjadi mitra dalam kegiatan ini adalah: ibu Choirul Mahpuduah (Pawon Kue), ibu Ana Masridah (Ananda Snack), ibu Miftahchul Chusnah (Angga Cake), ibu Elfa Susanti (Dieva Cake), ibu Ika Rahayu (TanzRisol Mayo), ibu Kinarti (Kennesh Cake), dan ibu Sumiatun (Kreasi Fitri).

\section{HASIL DAN PEMBAHASAN}

Berdasarkan hasil analisis pemetaan masalah, maka tim merencanakan dan melaksanakan program kerja yang sangat diperlukan perempuan pedagang kue di Kampung Kue sebagai berikut:

\section{A. Pembuatan Standard Operating Prosedur (SOP)}

Thomson etal (2017) menegaskan pentingnya hubungan stuktur organisasi dan perkembangannya dimana pada awalnya adalah entrepreneurial stracture, kemudian berkembang menjadi fungsional. Hal tersebut sesuai dengan kondisi ibu-ibu pedagang kue di Kampung Kue, yaitu tidak ada pembagian tugas, jumlah pegawai sedikit, dan sangat tergantung dengan pemilik. Pendampingan menekankan pentingnya peran kepemimpinan dan struktur organisasi agar usaha mengalami perkembangan. Standard Operating Prosedur (SOP) merupakan tahap kegiatan untuk menyelesaikan aktivitas atau metode langkah demi langkah dalam menyelesaikan masalah (Fatimah, 2015). SOP memuat tujuh hal pokok, yaitu efisiensi, konsisten, minimalisasi kesalahan, penyelesaian masalah, perlindungan tenaga kerja, peta kerja, dan batasan petahanan (Santoso 2014). Hasil 
Pengembangan Pedagang Kue Melalui Networking di Kampung Kue Rungkut Lor, Kecamatan Rungkut, Surabaya Maria Widyastuti, Andreas, Aldo, Alfredo

penelitian Soetijoso (2019) menunjukan pentingnya SOP dalam meningkatkan produktifitas dan pemasaran (Gabriele, 2018) bagi usaha mikro kecil dan menengah (UMKM) seperti pedagang kue di Kampung Kue. Hasil tersebut senada dengan penelitian di Malaysia (Jamaket al, 2017) mengenai faktor yang berpengaruh signifikan terhadap kesuksesan bisnis mikro adalah target yang terukur, efisiensi dan memiliki sistem atau proses yang teratur untuk meningkatkan motivasi pekerja.

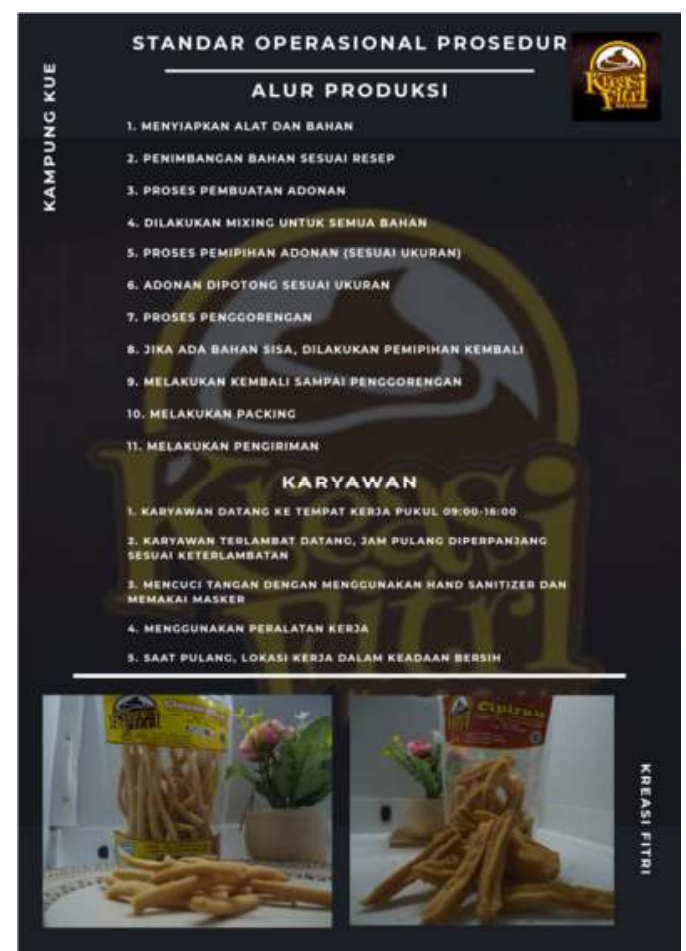

\section{Gambar 1. Standar Operasional Prosedur (SOP)}

\section{B. Pembuatan Pembukuan}

Pembukuan mempunyai peranan yang sangat penting untuk meraih keberhasilan usaha termasuk pedagang kue di Kampung Kue. Pembukuan merupakan informasi akuntansi berupa pencatatan keuangan yang merupakan modal awal untuk mengambilan keputusan dalam pengelolaan usaha. Dalam prinsip akuntansi pelaku usaha harus memisahkan keuangan perusahaan dengan keuangan pribadi (Weygandt et al, 2014). Terbatasnya akses kredit karena tidak adanya pembukuan sebagai informasi yang digunakan manajemen, calon investor maupun kreditor untuk menilai perkembangan usaha. Sebagian besar pedagang kue di Kampung Kue tidak mempunyai catatan secara terstruktur, bahkan sebagian besar hanya mengandalkan ingatan untuk menghitung berapa pendapatan yang diperoleh dan berapa biaya yang harus dikeluarkan berdasarkan kualitas 
bahan yang digunakan. Seringkali pembukuan yang dilakukan hanya dalam pikiran dan ingatan. Hal tersebut juga diakui oleh Syariati (2012) dan Setiawan dkk (2015). Pada umumnya harga jual merupakan penjumlahan antara biaya produksi dengan keuntungan yang diinginkan, tidak jarang biaya produksi berdasarkan pesanan, sebagaimana yang diutarakan ibu Irul dan ibu Elva, hal ini yang disebut job order. Penelitian mengenai pentingnya pembukuan juga merupakan hasil penelitian Andarsari dan Dura (2018) dan Hapsari dkk (2017).

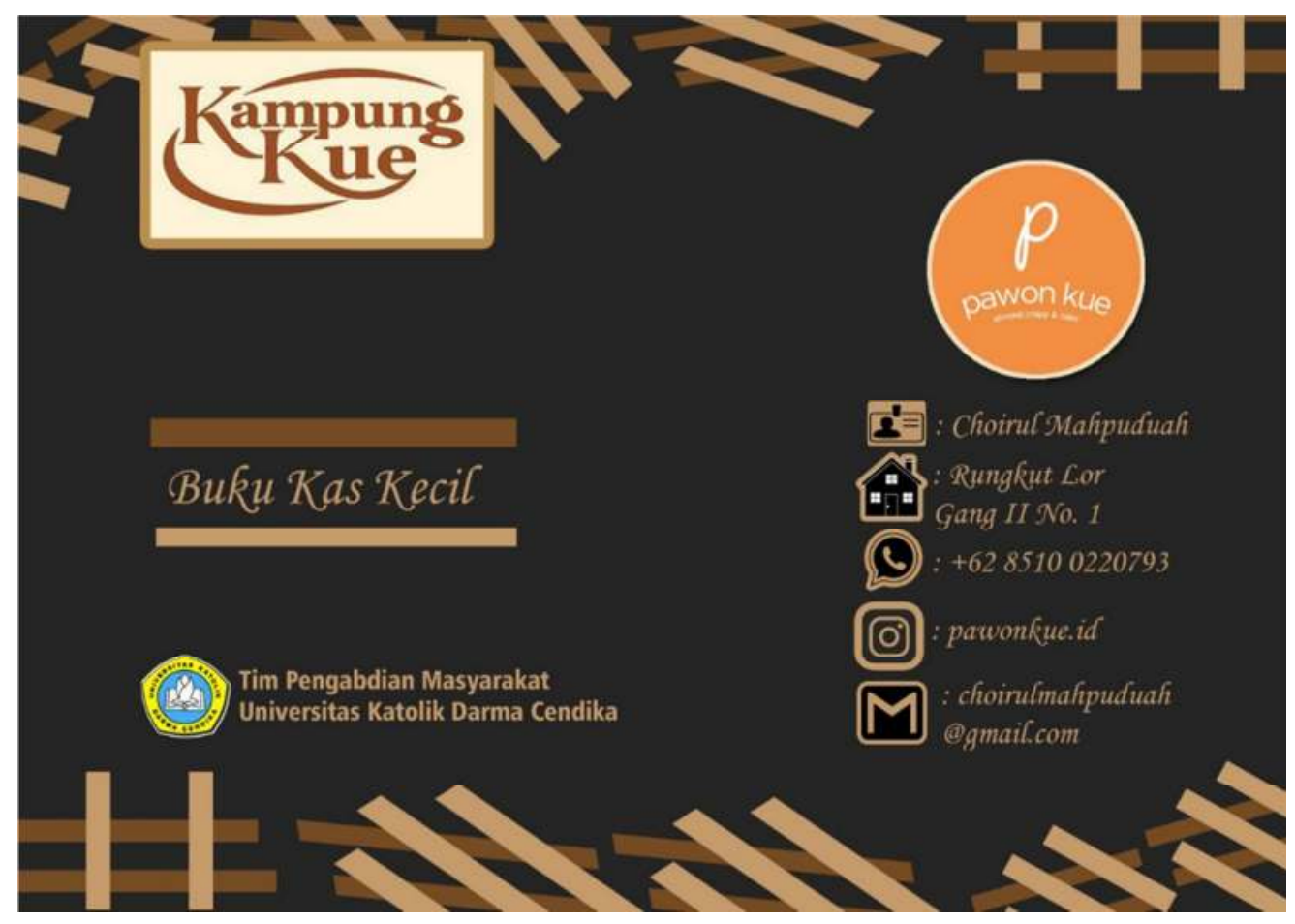

Gambar 2. Buku Kas Kecil

\section{Pembuatan Brosur}

Menurut Kotler dan Amstrong (2012), brosur merupakan salah satu sarana promosi yang dilakukan melalui media cetak. Brosur juga berfungsi untuk memberikan informasi dalam rangka memantapkan image guna menciptakan permintaan, maka perlu pembuatan brosur secara baik. Selama ini promosi yang dilakukan pedagang kue di Kampung Kue melalui instagram dan dari mulut ke mulut dimana kedua sarana tersebut jangkauannya tentu sangat terbatas. Tim menawarkan pembuatan brosur yang tujuannya mendukung kedua promosi yang sudah dilaksanakan sebelumnya dimana jangkauannya akan lebih luas dan tahan lama karena dapat disimpan dan sesuai dengan sasaran konsumen. Jumlah mitra ada tujuh, maka tim juga membuat tujuh macam brosur. Hasil penelitian Mezzalundi dan Talar (2019) menyarankan sebaiknya dalam pembuatan brosur harus mempertimbangkan 
Pengembangan Pedagang Kue Melalui Networking di Kampung Kue Rungkut Lor, Kecamatan Rungkut, Surabaya

Maria Widyastuti, Andreas, Aldo, Alfredo

pemilihan warna, kekontrasan, kualitas kertas, menggunakan kata-kata yang unik atau lucu. Hasil penelitian Sahara (2017), Hedynata dan Radianto (2016), dan Dellamita dkk (2014) menunjukkan pentingnya promosi melalui media cetak dimana salah satunya adalah brosur, agar produk yang dihasilkan lebih dikenal dan diminati konsumen dengan jangkauan yang luas.
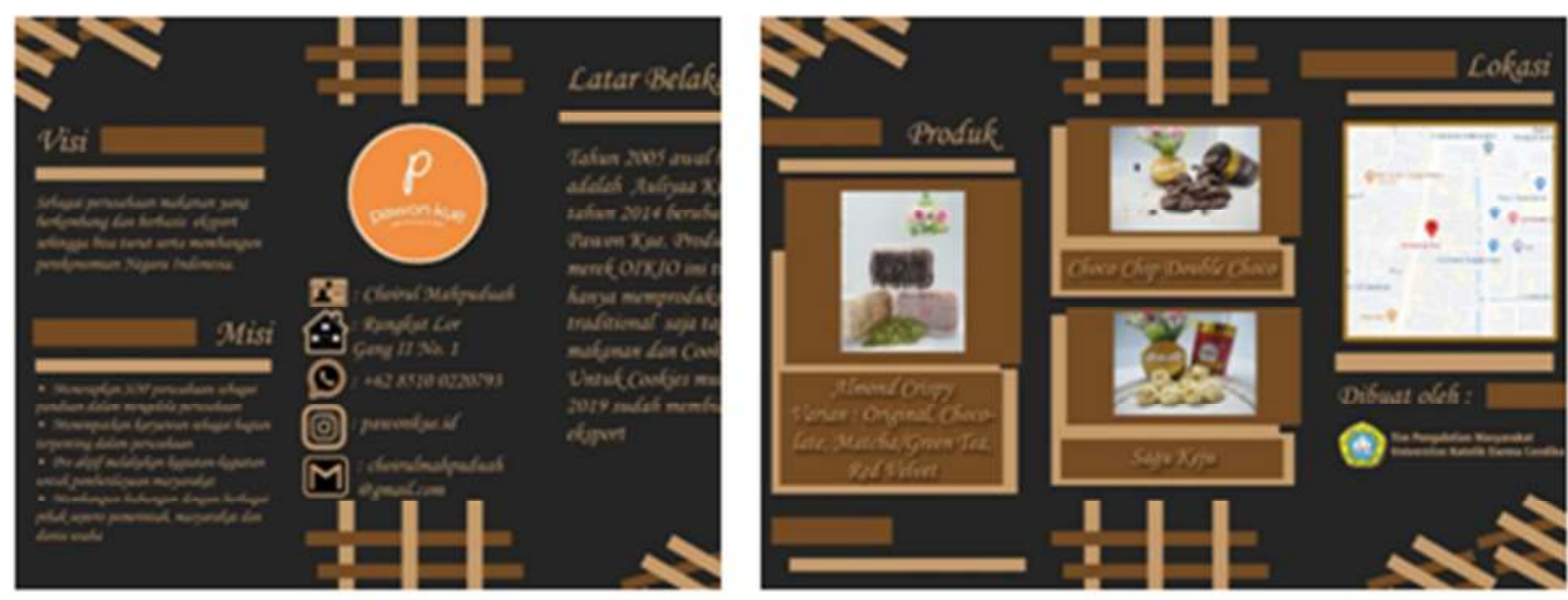

Gambar 3. Brosur Pawon Kue

\section{Pembuatan Katalog}

Katalog secara umum dapat diartikan suatu daftar yang berisi informasi tertentu mengenai benda atau barang yang didaftar. Tujuan katalog adalah untuk memudahkan seseorang dalam menemukan apa yang dicari, memperlihatkan apa yang dimiliki dan memperkenalkan produk dengan spesifikasinya. Selama ini pedagang kue di Kampung Kue belum mempunyai daftar yang menggambarkan semua jenis kue yang dihasilkan. Melalui kegiatan ini tim membantu membuat katalog yang fungsingya mendukung sarana promosi yang sudah ada, juga dapat sebagai sarana informasi secara menyeluruh mengenai profil, support, visi-misi, struktur organisasi, produk yang dihasilkan pedagang kue di Kampung Kue.

Hasil penelitian Ulumuddin dkk (2018) menunjukkan bahwa media katalog merupakan media yang terjangkau dan efektif. Media katalog berisi informasi mengenai produk. Informasi yang dicantumkan yaitu nama, spesifikasi, dan harga produk tersebut. Gambaran produk dapat dilihat dengan jelas melalui informasi foto produk yang ditampilkan di media katalog. Berkebalikan dengan media mulut ke mulut yang hanya bisa didengarkan tanpa adanya gambaran produk dengan jelas. Melalui media katalog, konsumen mendapat informasi lebih jelas mengenai gambaran produk olahan. Penelitian 
Aristi dan Rawana (2018) menemukan bahwa pembuatan katalog merupakan tahapan untuk menjalin keterbukaan, kepercayaan dan memahami persepsi, sikap serta pengalaman dan persoalan yang dimiliki pedagang kue di Kampung Kue dalam mendukung pengembangan pemasaran. Selanjutnya, hasil penelitian Chrismardana (2014) dan Slamet dkk (2016) menunjukkan pentingnya katalog sebagai sarana untuk menjelaskan suatu produk.

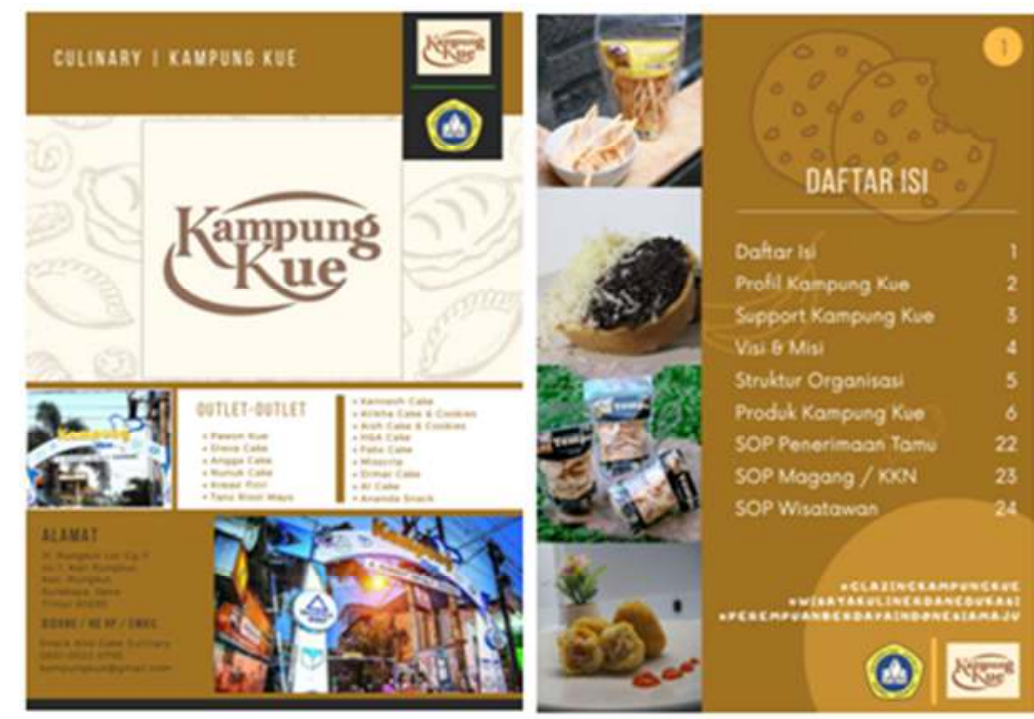

Gambar 4. Katalog Tentang Kampung Kue

\section{E. Pembangunan Rangkaian Sprinkle Spray Desinfektan}

Terkait dengan situasi sekarang ini yaitu merebaknya wabah virus corona yang sering disebut COVID-19, maka kami merasa terpanggil untuk ikut menjaga lingkungan tempat kegiatan pengabdian masyarakat dilaksanakan yaitu Kampung Kue, Rungkut Lor Surabaya, agar tidak terserang wabah tersebut. Sebagai bentuk kepedulian terhadap lingkungan, maka tim melaksanakan program "Pembangunan Rangkaian Sprinkle Spray Desinfektan” yang akan dipasang pada gerbang Kampung Kue dengan harapan warga terhindar dari virus tersebut, wabah cepat berakhir, dan pedagang kue dapat melaksanakan kegiatannya kembali. Dampak wabah Corona berupa penurunan penjualan pedagang kue hingga mencapai 50\% karena hanya melayani pesanan saja. Pembangunan Rangkaian Sprinkle Spray Desinfektan direncanakan untuk jangka panjang juga, sehingga apabila wabah virus corona sudah berakhir, maka rangkaian tersebut dapat dipergunakan untuk budidaya tanaman hidroponik. 

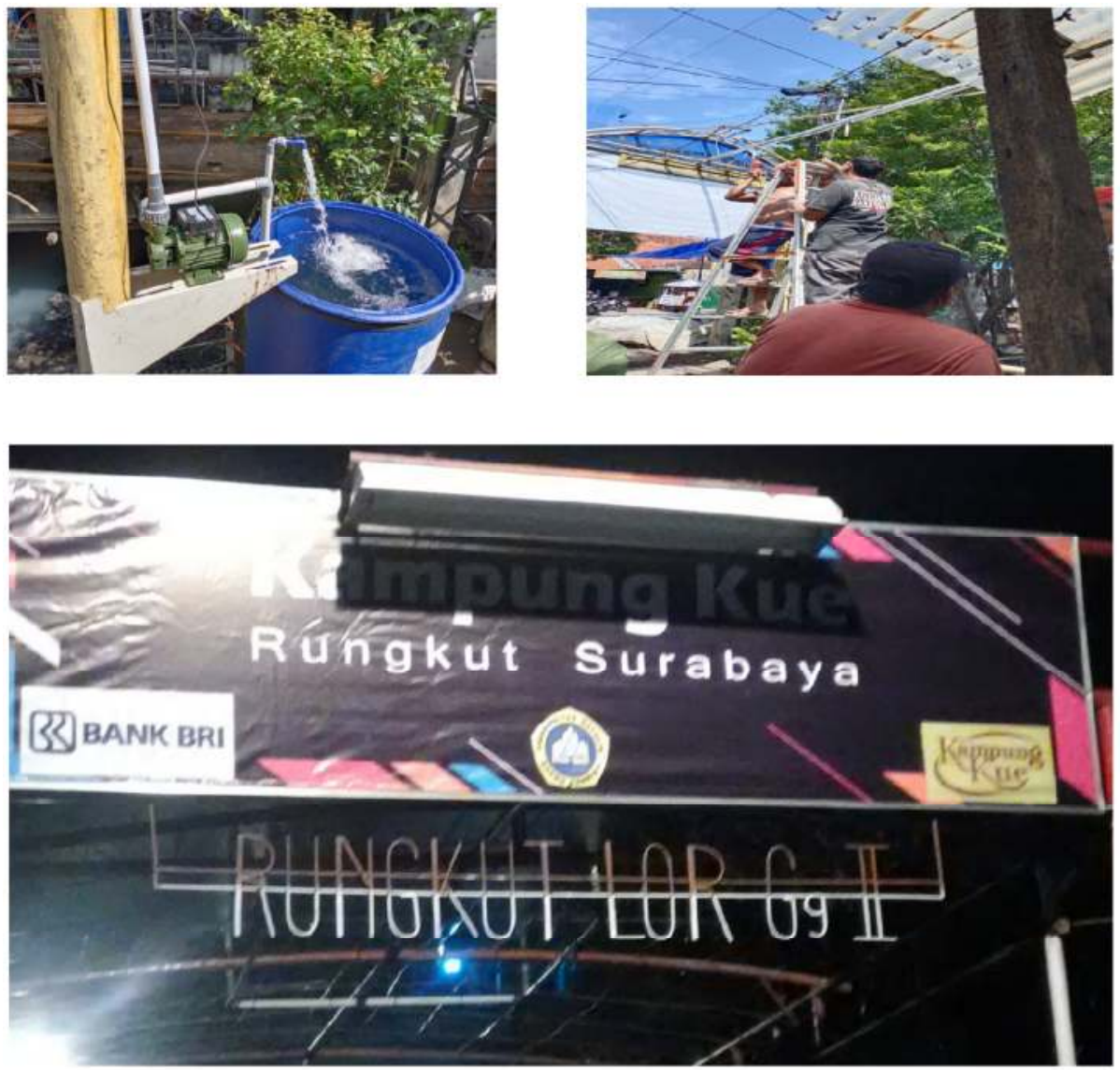

Gambar 5. Pembangunan Rangkaian Sprinkle Spray Desinfektan

\section{KESIMPULAN DAN SARAN}

Kegiatan Pengabdian Masyarakat yang dilakukan sangat membantu pedagang kue di Kampung Kue. Adanya Standard Operating Procedure (SOP) menjadikan pekerjaan menjadi lebih efisien dan konsisten, kesalahan dapat diminimalisir, penyelesaian masalah dapat cepat ditangani, dan adanya perlindungan tenaga kerja, Program tim berupa pembuatan pembukuan dapat memudahkan dalam mengetahui jumlah pemasukan, pengeluaran dan sisa uang, juga munculnya pemahaman bahwa uang yang digunakan untuk usaha harus dipisahkan dengan uang untuk keperluan sehari-hari. Adanya pembukuan akan memudahkan pedagang kue untuk mendapatkan kredit karena pembukuan dapat mencerminkan perkembangan usaha.

Perkembangan pedagang kue agar dikenal masyarakat yang lebih luas perlu didorong dengan melengkapi sarana promosi yang sudah ada, yaitu dengan pembuatan brosur dan katalog dengan memperhatikan pemilihan warna, kekontrasan, kualitas kertas, dan menggunakan kata-kata yang menarik. Sebagai bentuk kepedulian terhadap lingkungan terkait adanya virus corona atau disebut COVID 19, maka tim melaksanakan program 
“Pembangunan Rangkaian Sprinkle Spray Desinfektan” yang akan dipasang pada gerbang Kampung Kue dengan harapan warga terhindar dari virus tersebut.

Tim kegiatan menyarankan program-program yang sudah dibuat agar secara periodik dievalusi dan dilakukan perbaikan seperlunya yang disesuaikan dengan perkembangan sehingga dapat mengikuti perubahan yang terjadi. Rangkaian Sprinkle Spray Desinfektan yang dibuat jika wabah COVID 19 sudah tidak ada, maka rangkaian sprinkle spray dapat dimanfaatkan untuk budidaya tanaman hidroponik .

\section{UCAPAN TERIMA KASIH}

Terselenggaranaya kegiatan Pengabdian Masyarakat berkat dari bantuan dari berbagai pihak, maka pada kesempatan ini kami mengucapkan terima kasih kepada Universitas Katolik Darama Cendika yang telah memberikan dukungan dana. Demikian juga Bank Rakyat Indonesia (BRI) Pusat Jakarta yang telah mensponsori kegiatan dengan memberikan bantuan dana, Peran Bapak Trisnanto Rinaldy selaku Ketua RT yang telah sangat mendukung pelaksanaan kegiatan, Agar kegiatan ini lebih terarah kami juga mengucapkan terima kasih kepada ibu Choirul Mahpuduah sebagai penggagas berdirinya Kampung Kue yang memberikan arahan mengenai pelaksanaan kegiatan. dan terakhir kami mengucapkan terima kasih kepada ibu-ibu di Kampung Kue yang telah meluangkan waktunya untuk memberikan keterangan yang kami perlukan sehingga kegiatan dapat berjalan dengan lancar dan penuh kekeluargaan.

\section{DAFTAR PUSTAKA}

Andarsari, P.R. dan J. Dura. (2018). Implementasi Pencatatan Keuangan Pada Usaha Kecil dan Menengah (Studi pada sentra Industri kripik Tempe Sanan di Kota Malang). Jurnal JIBEKA, 12(1), 59-64.

Aristi, G. dan Rahwana, K.A. (2018). Implementasi E-Commerce Sebagai Katalog Produk Untuk Meningkatkan Pemasaran Produk UMKM di Kelurahan Sukahurip Kecamatan Tamansari Kota Tasikmalaya, Jurnal Technoper, 2, 1-14.

Budiyanto, E. \& Mochklas, M. (2020). Kinerja Karyawan Ditinjau dari Aspek Gaya Kepemimpinan, Budaya Organisasi Dan Motivasi Kerja (Pendekatan Riset). Banten: CV. AA. Rizky.

Chrismardani, Y. (2017). Komunikasi Pemasaran Terpadu: Implementasi Untuk UMKM Jurnal NeO-Bis, 8(2), 176 -189.

Dellamita, M.F., Fauzi, A. dan Yulianto, E. (2014). Penerapan Personal Selling Untuk meningkatkan Penjualan . Jurnal Administrasi Bisnis (JAB), 9(2), 1-6.

Fatima, N.E. (2015). Strategi Pintar Menyusun SOP (Standard Operating Procedure) Penerbit Pustaka Baru Press Yogyakarta.

Gabriele. (2018). Analisis Penerapan Standar Operasional Prosedur di Departemen Marketing dan HRD PT Cahaya Indo Persada. Jurnal AGORA Vol 6, No 1 
Hapsari, D.P., Andari dan Hasanah, A.N. (2017). Model Pembukuan Sederhana Bagi Usaha Mikro Di Kecamatan Kramatwatu Kabupaten Serang, Jurnal Akuntansi, 4(2), $36-47$.

Hedynata, M.L., dan Radianto, W.E.D. (2016). Strategi Promosi Dalam Meningkatkan Penjualan Luscious Chocolate Potato Snack. Jurnal Manajemen dan Start-Up Bisnis (PERFORMA), 1(1), 87-96.

Jamak, A.B.S.A, Ghazali, Z., dan Sharif, M.A.M. (2017). Micro - entreprise growth. Strategic Management Journal Vol 6, Issue 3 p 257-272

Kotler, P., dan Amstrong, G. (2012). Principles of Marketing: Global Edition (14 $\left.{ }^{\text {th }} \mathrm{ed}\right)$ New Jersey, US Pearson Education. Inc

Mezzalundi, F. dan Talar, Y. (2019). Usulan Strategi Promosi Untuk Meningkatkan Penjualan PT. Antar Putra Motor di Bandung Barat. Journal of Integrated System, 2(1), 21-36.

Mochklas, M. \& Hariri, A. (2019). Pelatihan Manajemen dan Produksi Untuk Meningkatkan Usaha Para Purna Tenaga Kerja Wanita (TKW) Di Solokuro Lamongan. Seminar Nasional Hasil Riset dan Pengabdian Ke-II (SNHRP-II) UNIPA Surabaya.

Mochklas, M., Rusmawati, Z., Santoso, A. \& Jannah, R. (2019). Pendampingan Kampung Pendidikan Kampung'e Arek Suroboyo (KP KAS) RW 03 Kelurahan Ketintang Surabaya. Jurnal Komunitas, 2(2): 51-59.

Oktaviani, M., \& Mochklas, M. (2020). Free Cash Flow, Size, and Earning Management. Proceedings of the 1st Borobudur International Symposium on Humanities, Economics and Social Sciences (BIS-HESS 2019). DOI https://doi.org/10.2991/assehr.k.200529.013

Rofi'i, N.A., Fatihudin, D. \& Mochklas, M. (2019). Pengaruh Strategi Bauran Pemasaran Terhadap Peningkatan Penjualan Pada Produk Dr. Kebab Bara Satriya Sidoarjo. Balance, 16(1): 112-119.

Sahara, S.T. (2017). Pelaksanaan Promosi Melalui Media Cetak Brosur pada Obyek wisata Balai Kerapatan Tinggi Kabupaten Siak. JOM FISIP, 4(2), 1-11.

Santoso. J.K. (2014). Lebih Memahami SOP, Surabaya: Kata Pena.

Sembiring, M.J., Fatihudin, D., Mochklas, M., \& Holisin, I. (2020). Banking Employee Performance During Pandemic Covid-19: Remuneration And Motivation. Journal of Xi'an University of Architecture \& Technology, Volume XII, VII, 64-71.

Slamet R, Nainggolan, B., Roessobiyatno, Ramdani, H., Hendriyanto, A. dan Ilma, L.L. (2018) Strategi Pengembangan UKM Digital Dalam Menghadapi Pasar Bebas. Jurnal Manajemen Indonesia, 16(2), 136-147.

Soetijoso, W.W., Saputera, M.I., Amindhita, S., Dwiputra, M., Andika, R., Gerardo, E., Putra, A.S. dan Paramita, K. (2019). Peningkatan Produktivitas UMKM Kue Kering dan Tik Tuk di Desa Cipanas Melalui Program Pendampingan Community Development. Jurnal Pengabdian Masyarakat (JPM, 1(1), 53-64.

Thompsom, J., Scott, J.M. dan Martin, F. (2017). Strategic Management Awareness and Change. Andover Cengage Learning EMEA. 